\title{
Effect of Dietary Supplementation of Yeast on Growth, Feed Conversion Efficiency and Cost of Feeding in Surti Goat Kids
}

\author{
S.K. Pradhan*, M. Choubey, V.R. Patel, V.B. Kharadi and V.S. Dabas \\ Department of Animal Science, N. M. College of Agriculture, Navsari Agricultural University, \\ Navsari-396 450, Gujarat, India \\ *Corresponding author
}

A B S T R A C T

\begin{tabular}{|l|}
\hline Ke y w or d s \\
Goat, Yeast, \\
Growth, Feed \\
efficiency, \\
Economics \\
\hline Article Info \\
\hline Accepted: \\
12 August 2018 \\
Available Online: \\
10 September 2018 \\
\hline
\end{tabular}

An experiment was conducted to evaluate the effect of yeast supplementation on growth, feed conversion efficiency and cost of feeding in Surti goat kids. A total of 16 male Surti goat kids of four months old were selected with average body weight of $7.53 \pm 0.13 \mathrm{Kg}$. Animals were randomly divided in to two groups with eight replication per group. Active dried yeast (S. cerevisiae CNCM I-1077) was supplemented in one experimental group at the rate of $2 \%$ of DMI, and the second group without any supplementation was control. The feed intake was measured daily for 80 days and body weight was taken on first and eighth day of the experiment. The result shows that there was significant $(P<0.05)$ improvement in body weight gain, feed efficiency and cost economics in supplemented group without affecting the feed intake between the control and supplemented group. Hence it was concluded that supplementation of active dried yeast (S. cerevisiae CNCM I1077 ) at $2 \%$ of dry matter intake would improve the growth, feed conversion efficiency and cost of feeding in surti goat kids.

\section{Introduction}

Small ruminant farming is still the major chunk of livelihood among the small and marginal farmers in India. Agricultural byproducts and crop residues represents a potential source of dietary nutrients for these animals. These resources are generally deficient in readily available source of energy, protein and other micronutrients. More over the high fiber content of these feed resources restrict the accessibility of ruminal microbes thereby their digestibility (Tan et al., 1995). In recent years, use of probiotics has been used to manipulate the rumen microbial ecosystem to enhance the nutritive value and utilization efficiency of low-quality roughages (Tang et $a l ., 2008)$. Among the different microbial feed additives, Saccharomyces cerevisiae and Aspergillus oryzae are more effective in rumen, whereas lactobacilli are effective during pre-ruminant stage (Khuntia and Chaudhary, 2002). Yeast culture supplementation in ruminant diets can increase dry matter intake (DMI), production performance, cellulose degradation, and nutrient digestibility (Lesmeister et al., 2004). In vitro studies have also shown that yeast culture favorably modified the mixed ruminal microorganism fermentation and stimulated 
cellulose digestion by pure cultures of predominant ruminal bacteria (Lynch and Martin, 2002; Miller et al., 2002). However, the effects of Yeast culture on animal productivity are strain-dependent. There is a lot of variation in the performance of same animal fed on different species of probiotic, or even the same species but different strain of probiotic (Kamal et al., 2013; Newbold et al., 1996). Therefore, the present study was undertaken to assess the effect of live YC (Saccharomyces cerevisiae CNCM I-1077) supplementation on growth performance and nutrient utilization in Surti goat kids.

\section{Materials and Methods}

\section{Anima housing treatment and experimental design}

The experiment was conducted at livestock Research station, Navsari Agricultural University, Navsari. Sixteen male Surti goat kids of weighing 7.53 \pm 0.13 (4-month-old) were selected for this experiment. The animals were housed in individual pens $(1 \mathrm{~m} \times 2 \mathrm{~m})$. In the first day all kids were dewormed with albendazole $(10 \mathrm{mg} / \mathrm{kg} \mathrm{B.W})$. The pens were cleaned and disinfected by normal disinfectant before the onset of the experiment. The animals were randomly assigned to one of two different treatments with eight animals per treatment following the completely randomized design. Active dry yeast consists of pure dried yeast cells ( $S$. cerevisiae $\mathrm{CNCM}$ I-1077) with viability counts ranging from 1525 billion live yeasts cells or colony forming units (CFU) per gram was procured from Lallemand Animal nutrition, France. Active dried yeast (S. cerevisiae CNCM I-1077) was supplemented in one experimental group at the rate of $2 \%$ of DMI, and the second group without any supplementation was control. The animals were fed a concentrate and roughage based diet to fulfill their nutrient requirement as per the recommendation of ICAR (2013)
(Table 1). The animals had a free access to clean drinking water. Standard management practices were followed under uniform conditions.

\section{Animal studies}

Feed intake was recorded daily throughout the 80-days of experimental period and the body weight of the animals was recorded at the beginning and the end of the experimental period.

\section{Statistical analysis}

Data were subjected to analysis of variance according to Steel and Torrie (1960). The comparison among means was analyzed by the least significant difference using LSD procedure of the Statisticx ${ }^{\circledR}$ (Analytical Software, 2000).

\section{Results and Discussion}

The result of supplementation of Saccharomyces cerevisiae CNCM I-1077) on growth, feed conversion efficiency and cost of feeding in Surti goat kids is given in table 2 . The average body weight gain of kids was significantly $(P<0.05)$ higher in the supplemental group in comparison to the control group. There are series of study in goats (Özsoy et al., 2013; Kamal et al., 2013) and in lambs (Haddad and Goussous, 2005), which reported that live yeast supplementation increased live weight gain. However Titti et al., (2008), reported that yeast culture supplementation has no effect on feed intake and growth but reported an increased digestibility of nutrients. In the present study the supplementation of yeast did not affect the feed intake which is in agreement with Titti et al., (2008), however the increased digestibility of nutrients may be the reason for increased average body weight in the yeast supplemented group. 
Table.1 Proximate analysis of the feed offered on dry matter base

\begin{tabular}{|l|c|c|c|}
\hline \multicolumn{1}{|c|}{ Proximate } & Concentrate & Green fodder & Dry fodder \\
\hline Organic Matter \% & 94.2 & 89.85 & 86.78 \\
\hline Crude Protein (N*6.25) \% & 17.84 & 7.14 & 7.58 \\
\hline Ether Extract \% & 2.92 & 3.32 & 1.67 \\
\hline Total Carbohydrate \% & 73.44 & 79.39 & 77.53 \\
\hline Neutral Detergent Fiber \% & 23.24 & 49.13 & 54.88 \\
\hline Acid Detergent Fiber \% & 14.85 & 31.46 & 37.56 \\
\hline Hemi-cellulose \% & 8.39 & 17.67 & 17.32 \\
\hline Ash \% & 5.8 & 10.15 & 13.22 \\
\hline
\end{tabular}

Table.2 Effect of yeast (Saccharomyces cerevisiae CNCM I-1077) supplementation on growth, feed conversion efficiency and cost of feeding in Surti goat kids

\begin{tabular}{|c|c|c|c|c|}
\hline Sr. No. & Parameters & Control & Supplemented group & p value \\
\hline 1 & Initial Body weight (Kg) & $7.49 \pm 0.11$ & $7.57 \pm 0.15$ & 0.634 \\
\hline 2 & Final Body Weight & $11.77^{\mathrm{a}} \pm 0.15$ & $12.43^{b} \pm 0.13$ & 0.004 \\
\hline$\overline{3}$ & Growth rate $(\mathrm{g} / \mathrm{d})$ & $52.43^{\mathrm{a}} \pm 2.70$ & $61.73^{b} \pm 2.67$ & 0.028 \\
\hline 4 & $\operatorname{DMI}(\mathrm{g} / \mathrm{d})$ & $474.50 \pm 7.92$ & $476.98 \pm 8.55$ & 0.814 \\
\hline 5 & Feed/Gain ratio & $9.25^{b} \pm 0.345$ & $7.78^{\mathrm{a}} \pm 0.453$ & 0.022 \\
\hline 6 & $\mathrm{DMI} / \mathrm{W}^{0.75}$ & $75.04^{b} \pm 0.94$ & $71.67^{\mathrm{a}} \pm 1.17$ & 0.042 \\
\hline 7 & Feed Cost/kg Gain (Rs) & $82.79^{b} \pm 3.28$ & $69.40^{\mathrm{a}} \pm 2.98$ & 0.009 \\
\hline
\end{tabular}

Means bearing different uppercase superscript letters in row differ significantly $(\mathrm{P}<0.05)$.

Table.3 Effect of yeast (Saccharomyces cerevisiae CNCM I-1077) supplementation on benefit cost ratio in Surti goat kids

\begin{tabular}{|c|c|c|c|c|c|c|c|}
\hline Treatment & Number & $\begin{array}{c}\text { final } \\
\text { B.W }\end{array}$ & $\begin{array}{c}\text { Gain in } \\
\text { B.W }\end{array}$ & $\begin{array}{c}\text { Total operational } \\
\text { cost Rs. }\end{array}$ & $\begin{array}{c}\text { Gross } \\
\text { income }\end{array}$ & $\begin{array}{c}\text { Net } \\
\text { income }\end{array}$ & BC ratio \\
\hline Control & 8 & 11.77 & 4.28 & 354.34 & 963.00 & 608.66 & 1.71 \\
\hline $\begin{array}{c}\text { Yeast } \\
\text { supplemented }\end{array}$ & 8 & 12.43 & 4.86 & 337.284 & 1093.5 & 756.22 & 2.24 \\
\hline
\end{tabular}

Feed cost - Rs. 16/kg; Dry and green fodder- Rs. 5/kg; Dressing percentage- $50 \%$; Chevon market rate- Rs. 450/kg; B.W: Body Weight; BC ration: Benefit Cost ratio;

The significant $(P<0.05)$ increase in average daily gain without any affecting the daily feed intake resulted in an significant improvement in feed efficiency and cost benefit ratio in surti goat kid supplemented with yeast. The similar finding was also reported by Kamal et al., (2013) (Table 3).
Supplementation of yeast (Saccharomyces cerevisiae CNCM I-1077) @ 2\% of DMI to Surti goat kids of 4-6 month age shows significant improvement in growth rate and feed conversion efficiency without affecting dry matter intake. 
Age shows significant improvement in growth rate and feed conversion efficiency without affecting dry matter intake.

\section{Acknowledgement}

The author is very much thankful to Lallemand Animal Nutrition, France for providing the dried yeast culture and principal N M College of Agriculture for providing financial support for the completion of this research programme.

\section{References}

Haddad, G., Goussous, S.N. (2005): Effect of yeast culture supplementation on nutrient intake, digestibility and growth performance of Awassi lambs. Animal Feed Science and Technology, Volume 118. pp. 343-348.

Jinturkar, A.S., Gijar, B.V., Chauhan, D.S., Patil, R.A. 2009. Effect of feeding probiotics on the growth performance and feed conversion efficiency in Goat. Indian Journal of Animal Research, Volume 43. Number 1.pp. 49-52.

Kamal, R., Dutta, T., Singha, M., Kamrab, D.N., Patel, M., Choudharyb, L.C., Agarwalb, N., Kumarc, S., Islama, M. (2013): Effect of live Saccharomyces cerevisiae (NCDC-49) supplementation on growth performance and rumen fermentation pattern in local goat. Journal of Applied Animal Research, Volume 41. Number 3. pp. 285-288.

Khuntia A, Chaudhary LC. 2002. Performance of male crossbred calves as influenced by substitution of grain by wheat bran and the addition of lactic acid bacteria to diet. Asian-Aust J Anim Sci. 15(2):188-194.

Lesmeister, K. E., A. J. Heinrichs, and M. T. Gabler. 2004. Effects of supplemental yeast (Saccharomyces cerevisiae) culture on rumen development, growth characteristics, and blood parameters in neonatal dairy calves. J. Dairy Sci. 87:1832-1839.

Lynch, H. A., and S. A. Martin. 2002. Effects of Saccharomyces cerevisiae culture and Saccharomyces cerevisiae live cells on in vitro mixed ruminal microorganism fermentation. J. Dairy Sci. 85:2603-2608.

Miller-Webster, T., W.H. Hoover, M. Holt and J.E. Nocek. 2002. Influence of yeast culture on ruminal microbial metabolism in continuous culture. J. Dairy Sci., 85: 20092014

Newbold, C.J., McIntosh, F.M. and. Wallace, R.J. 1996. Mode of action of the yeast, Saccharomyces cerevisiae, as afeed addative for ruminants. Br. J. Nutr. 76:249261.

Özsoy, B., Yalçin, S., Erdoğan, Z., Cantekin, Z., Aksu, T. (2013): Effects of dietary live yeast culture on fattening performance on some blood and rumen fluid parameters in goats. Revue de Médecine Vétérinaire, Volume 164. Number 5. pp. 263-271.

Tan, Z. L., Chen, H. P., He, L. H., Fang, R. J., and Xing, T. X. 1995. Variation in the nutritional characteristics of wheat straw. Anim. Feed Sci. Technol. 53:337-344.

Tang S. X, G. O. Tayo, Z. L. Tan, Z. H. Sun, L. X. Shen, C. S. Zhou, W. J. Xiao, G. P. Ren, X. F. Han, and S. B. Shen. 2008. Effects of yeast culture and fibrolytic enzyme supplementation on in vitro fermentation characteristics of low-quality cereal straws. J. Anim. Sci. 2008. 86:1164-1172

Titti, H.H., Dmour, R.O., Abdullah, A.Y. (2008): Growth performance and carcass characteristics of awassi lambs and shami goat kids fed yeast culture in their finishing diet. Animal Feed Science and Technology, Volume 142. pp. 33-43.

\section{How to cite this article:}

Pradhan, S.K., M. Choubey, V.R. Patel, V.B. Kharadi and Dabas, V.S. 2018. Effect of Dietary Supplementation of Yeast on Growth, Feed Conversion Efficiency and Cost of Feeding in Surti Goat Kids. Int.J.Curr.Microbiol.App.Sci. 7(09): 2032-2035.

doi: https://doi.org/10.20546/ijcmas.2018.709.246 